\title{
Potential Bioregulators for Rape (Brassica napus L.) Plants
}

\author{
Corneliu TANASE ${ }^{1 *}$, Valentin I. POPA ${ }^{2}$ \\ ${ }^{1}$ Pharmacy Faculty. University of Medicine and Pharmacy, Tirgu Mureș, 38 Gheorghe Marinescu Street, \\ 540139, Târgu Mureș, Romania. \\ ${ }^{2}$ Chemical Engineering and Environmental Protection Faculty. "Gheorghe Asachi” Technical University, \\ 73 Prof. Dr. Doc. Dimitrie Mangeron Street, 700050, Iasi, Romania \\ *corresponding author, e-mail: corneliu.tanase@umftgm.ro
}

Bulletin UASVM series Agriculture 73(1)/2016

Print ISSN 1843-5246; Electronic ISSN 1843-5386

DOI 10.15835/buasvmcn-agr: 11511

\begin{abstract}
It is known that polyphenols are a single group of phytochemicals which present in all plants. Their biological activity is based upon functional groups capable to participate in the plant metabolism influencing cell division and biosynthesis processes. In our experiments we have evaluated the effect of spruce bark polyphenolic extract and deuterium depleted water (DDW) as rapeseed plant bioregulators. After aqueous extraction of bark and quantification and identification of polyphenolic compounds by HPLC methods, we applied the extracts in the growth medium of rapeseed plants. Assessment the influence of extracts on rapeseed plants was achieved through determination of germination energy and capacity, biomass accumulation, assimilatory pigments accumulation and photosynthesis activity. The results has shown that it possible to establish the highest stimulating effect of polyphenols on germination energy and capacity. These, were registered in the presence of spruce bark polyphenolic extract (SBPE) with an equivalent content of $130 \mathrm{mg}$ GAE/L. Rape plants treated with DDW+SBPE have accumulated the highest amount of biomass compared with other experimental variants. The photosynthesis activity was considerably intensified especially in the presence of SBPE.
\end{abstract}

Keywords: spruce bark, polyphenols, deuterium depleted water (DDW), rape, bio regulators

\section{INTRODUCTION}

Rapeseed (Brassica napus L.) is one the largest oilseed crops. Growth and development of plants depend on environmental conditions. Recent researches has shown that SBPE and DDW have a great influence on development of plants, namely in developing cells and tissues and changes that occur in normal water features leading to significant changes in fundamental processes of biosynthesis (Tanase et al., 2012; Tanase et al., 2013).

\section{AIMS AND OBJECTIVES}

The aim of this study was to evaluate the effect of DDW and SBPE as rapeseed plant bio regulators. At the same time a combination of DDW with SBPE could be interesting to obtain information about their role in plant development.

\section{MATERIALS AND METHODS}

Spruce bark is a major waste product from forestry and wood processing industries. On the other hand DDW is a residue resulted in the heavy water obtaining. The extracts were characterized from the point of view of total content of polyphenols (mgGAE/L), tannins, flavonoids, flavonols, and antocyanins (Tanase et al., 2013).

The field experiment was performed in the field of Botanical Garden "Anastasie Fatu" of Iasi, over a period of 120 days from April to August, for two consecutive years (2010 and 2011), and was carried out in triplicates. The average value was reported. Tested solutions were the following: control - tap water, DDW, DDW in combination 1:1 with SPBE with an equivalent content of $191 \mathrm{mg}$ GAE/L (DDW + SBPE), SBPE with $130 \mathrm{mg} \mathrm{GAE} / \mathrm{L}$ (SBPE1) and SPBE with $191 \mathrm{mg}$ GAE/L (SBPE2). 
Tab. 1. Physiological indices for rapeseed grown under SBPE and DDW treatment

\begin{tabular}{ccccccc}
\hline \multirow{2}{*}{$\begin{array}{c}\text { Tested } \\
\text { solutions }\end{array}$} & \multicolumn{2}{c}{$\begin{array}{c}\text { Germination process (\%, } \\
\text { comparing with control) }\end{array}$} & \multirow{2}{*}{$\begin{array}{c}\text { Leaves number (\%, } \\
\text { comparing with control) }\end{array}$} & \multicolumn{2}{c}{$\begin{array}{c}\text { Biomass accumulation (\%, } \\
\text { comparing with control) }\end{array}$} \\
\cline { 3 - 4 } & Energy & Capacity & & & Stem + root & Leaves \\
\hline 1 & DDW & $33.23 \pm 0.21$ & $24.34 \pm 0.76$ & $15.74 \pm 0.21$ & $7.23 \pm 0.15$ & $13.23 \pm 0.07$ \\
\hline 2 & DDW+SBPE & $51.22 \pm 0.54$ & $38.44 \pm 0.65$ & $23.14 \pm 0.48$ & $35.11 \pm 0.25$ & $40.87 \pm 0.73$ \\
\hline 3 & SBPE1 & $55.54 \pm 0.81$ & $30.67 \pm 0.45$ & $31.48 \pm 0.59$ & $41.56 \pm 0.43$ & $55.63 \pm 0.87$ \\
\hline 4 & SBPE2 & $27.12 \pm 0.15$ & $15.19 \pm 0.26$ & $7.7 \pm 0.02$ & $3.22 \pm 0.04$ & $15.56 \pm 0.41$ \\
\hline
\end{tabular}

Tab. 2. Photosinthetic pigments contents and assimilation rate for rapeseed grown under SBPE and DDW treatment

\begin{tabular}{cccccccc}
\hline & $\begin{array}{c}\text { Tested } \\
\text { solutions }\end{array}$ & Chl a $(\mu \mathrm{g} / \mathrm{g})$ & $\mathrm{Chl} \mathrm{b}(\mu \mathrm{g} / \mathrm{g})$ & $\begin{array}{c}\text { Carotene } \\
(\mu \mathrm{g} / \mathrm{g})\end{array}$ & $\begin{array}{c}\text { Chl a+b } \\
(\mu \mathrm{g} / \mathrm{g})\end{array}$ & $\begin{array}{c}\text { chl a/b } \\
\begin{array}{c}\text { Assimilation rate }(\mathrm{A}, \\
\left.\text { imol CO } \mathrm{m}^{-2} \mathrm{~s}^{-1}\right),\end{array}\end{array}$ \\
\hline 1 & Control & $204.09 \pm 2.87$ & $39.62 \pm 0.56$ & $38.02 \pm 0.54$ & 243.71 & 5.15 & $14.65 \pm 0.07$ \\
\hline 2 & DDW & $282.12 \pm 2.54$ & $54.89 \pm 0.89$ & $54.89 \pm 1.02$ & 348.15 & 4.27 & $24.28 \pm 0.12$ \\
\hline 3 & DDW+SBPE & $285.89 \pm 2.98$ & $58.87 \pm 0.76$ & $58.87 \pm 1.11$ & 344.07 & 4.91 & $28.91 \pm 0.11$ \\
\hline 4 & SBPE1 & $272.85 \pm 3.01$ & $47.81 \pm 0.54$ & $47.81 \pm 0.97$ & 336.41 & 4.29 & $32.41 \pm 0.15$ \\
\hline 5 & SBPE2 & $252.29 \pm 2.13$ & $45.95 \pm 0.43$ & $45.95 \pm 0.65$ & 309.24 & 4.43 & $17.34 \pm 0.08$ \\
\hline
\end{tabular}

The amount of used solution was $10 \mathrm{~mL} /$ plant/ application.

To determine the biomass accumulation, ten plants for each experimental variant were harvested and separated into root, stems and leaves, at 120 days after seedling and then dried at $65^{\circ} \mathrm{C}$. The results obtained are the average from the ten samples. The assimilation rate $(\mathrm{A}, \mu \mathrm{mol}$ $\mathrm{CO}_{2} \mathrm{~m}^{-2} \mathrm{~s}^{-1}$ ), was determined with a $\mathrm{LCi}$ portable photosynthesis system. The concentrations of chlorophyll and carotenoids pigments were calculated using the specific coefficients suggested by Lichtenthaler and Wellburn (1983).

\section{RESULTS AND DISCUSSION}

The obtained results revealed that the used compounds have a stimulating germination energy and capacity for all experimental variants. The combination DDW + SBPE determines the highest degree of stimulation for the followed indices. Also, in case of SBPE1 (130 mg GAE / L) and DDW + SBPE (91 mg GAE / L) variants is recorded an increase of biomass yield, compared to control (Table 1). Photoassimilating pigments content, is higher in all experimental variants, compared to control. The highest rate of assimilation was recorded in the variant SBPE1 and DDW + SBPE (Table 2).

\section{CONCLUSION}

It was found that spruce bark polyphenolic extract (130 mg GAE / L) and DDW have a stimulating effect on all physiological indices recorded (germination energy and capacity, biomass accumulation, photosynthetic pigments contents and assimilation rate). DDW+SBPE combination, revealed a possible synergistic action. Based on presented results in the present work, we proposed to use SBPE and DDW as bio regulator in the cultivation of rape plants and to its effects on the seeds production.

\section{REFERENCES}

1. Lichtenthaler, HK., Wellburn, AR., (1983). Determinations of total carotenoids and chlorophylls $a$ and $b$ of leaf extracts in different solvents. Biochemical Society Transactions, 11, 591-598.

2. Tanase C., Volf I., Vintu S., Grădinaru R., Popa IV., (2013). Potential applications of wastes from energy and forestry industry in plant tissue culture, Cell. Chem. Tech. Vol. 47, 7-8, 553-563.

3. Tanase C., Volf I., Popa IV., (2012). Deuterium depleted water and spruce bark extract - bioregulators for maize and rape plants, Buletinul Institutului Politehnic din Iasi, Tomul LVIII , fasc. (2), 89-97. 